\title{
SOME WASP-LIKE BEES FROM GUATEMALA
}

\author{
By T. D. A. Cockerell \\ University of Colorado, Boulder, Colorado
}

The bees recorded below were, with one exception, collected by J. Bequaert in Guatemala. At first sight, the collection appears to consist of small wasps, and whatever any one may think about Müllerian mimicry, these resemblances must be admitted to be very remarkable, and to call for some explanation.

\section{Epeolus fulvopilosus Cameron}

Seventeen specimens, including both sexes. Finca Mocá near Guatalon, 1,000 m., at flowers of Synedrella nodiflora and Melampodium divaricatum. Finca Sa. Emilia near Pochuta, 1,000 m. This species was described in 1902, from a specimen caught on the west coast of Mexico by G. F. Matthew. This was a male. The female is similar, rather more robust, the fifth tergite with a short silvery-white lunule. The first tergite has a very broad pale fulvous band of tomentum. A related species is E. xanthurus Cockerell, from Ecuador. I said of this when describing (1917), "with the aspect of an Odynerid wasp."

\section{Megachile aurantipennis Cockerell}

Five specimens, both sexes. Mocá near Guatalon, 1,000 m.; Sa. Emilia near Pochuta, at flowers of Melampodium divaricatum. Described from Guatemala. Very closely allied to M. pulchriventris Ckll., from British Guiana.

\section{Osiris fasciatus (Radoszkowsky)}

One male; Mocá near Guatalon, 1000 m., April 26, 1931. Length about $11 \mathrm{~mm}$. Radoszkowsky described the female, from Orizaba, Mexico. The male is a little smaller, but 
agrees with the description, except that the scape is black, not yellow, and there is a broad dark brown band across the occiput. Noteworthy features are the thick ferruginous flagellum, the canary yellow face (with a little black band down each side of supraclypeal area and extending a little way down sides of clypeus), the dark mesothorax with two yellow bands, the yellowish wings with large pale orange stigma, the basal nervure falling considerably short of nervulus, and the abdomen with alternate bands of black and yellow. The legs are yellow, the hind femora and trochanters black beneath. The nearest relative appears to be O. mexicanus Cresson.

I have a note that Radoszkowsky's figure (not now available to me) shows a very short marginal cell, but Friese examined the type in the Berlin Museum, and found it to be an Osiris, as indeed the description sufficiently indicates. It was considered to represent a new genus Euthyglossa.

\section{Anthidiellum apicale (Cresson)}

One female; Amapala, Rep. Honduras, March 29, 1931 (D. M. Bates). Described from Mexico, as Anthidium apicale.

\section{Stelis (Protostelis) costaricensis Friese}

One female; Mocá near Guatalon. It differs slightly from Friese's description, based on specimens from Costa Rica, in that the venter of abdomen is entirely black, the first tergite has a slender transverse yellow stripe on disc, while the second has no yellow on disc, but a yellow spot (cuneiform in shape) at each side. The second recurrent nervure goes nearly as far beyond second cubital cell as the first is from the base of that cell.

\section{Halictus sericeus Friese}

One female; Sa. Emilia near Pochuta. Friese described this from a female collected at San Carlos, Costa Rica. The description agrees so closely with the Guatemala specimen that I cannot doubt the identity, though the hair at end of abdomen is pale fulvous rather than brown, and the hind tibiæ have pure white anteriorly. 

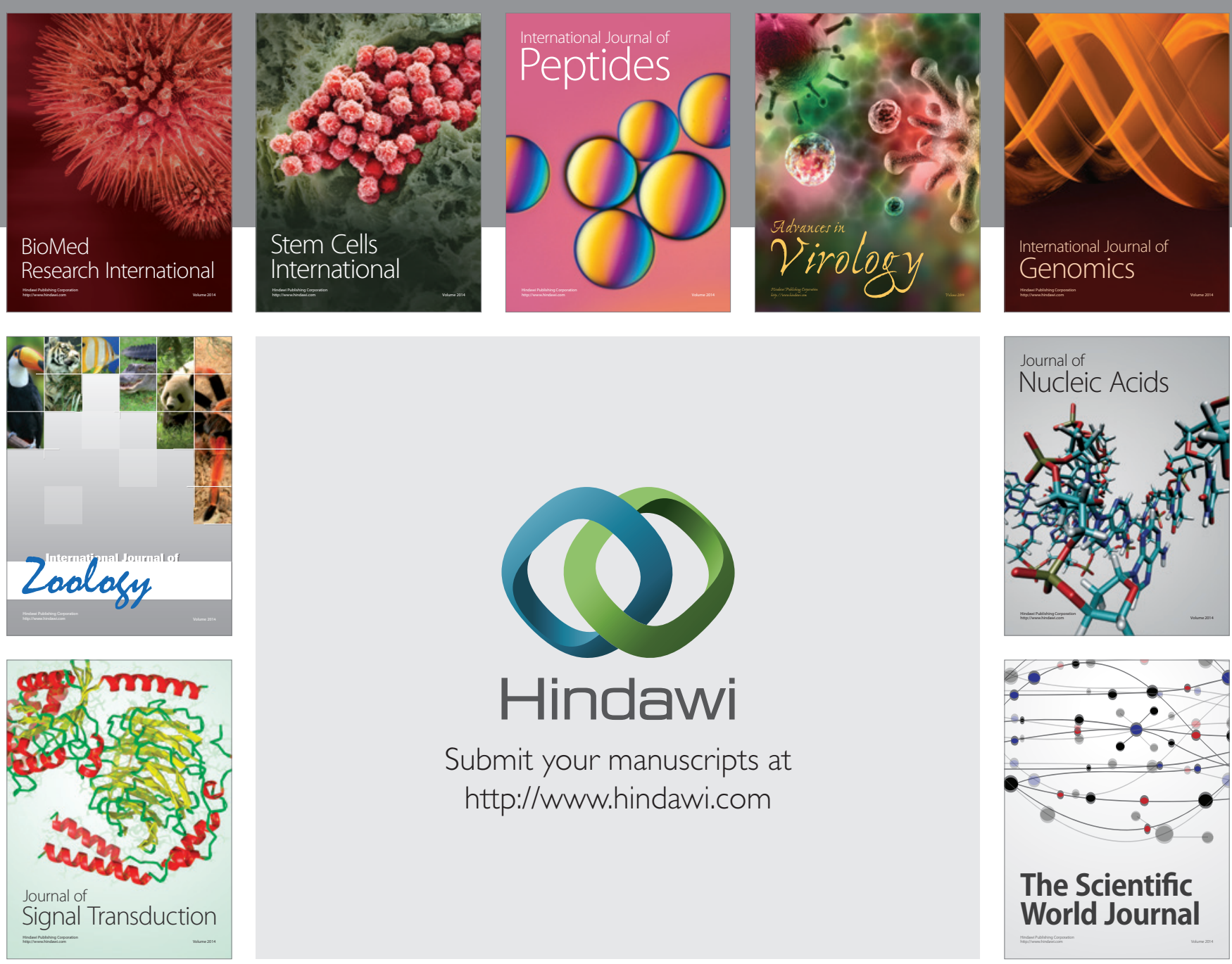

Submit your manuscripts at

http://www.hindawi.com
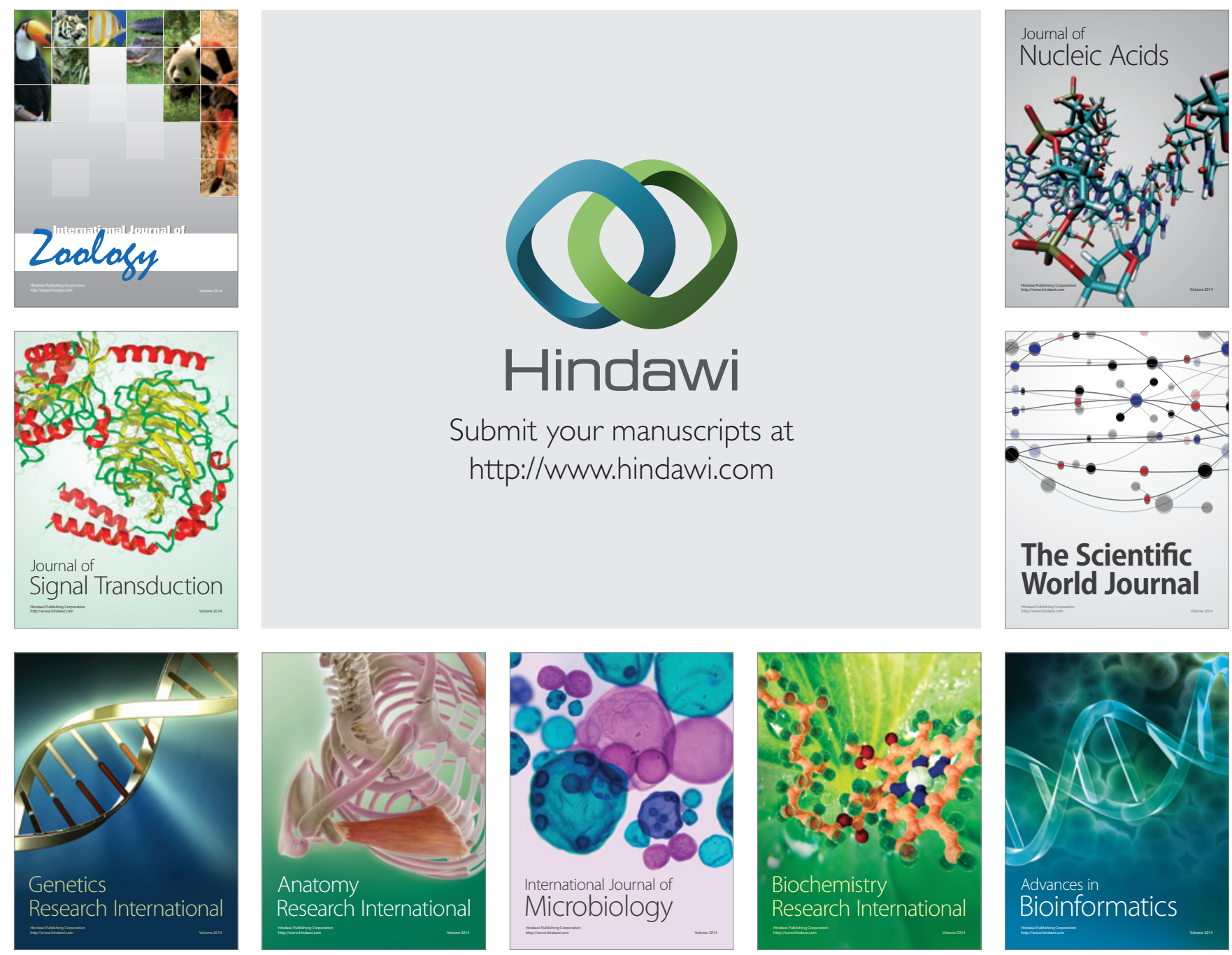

The Scientific World Journal
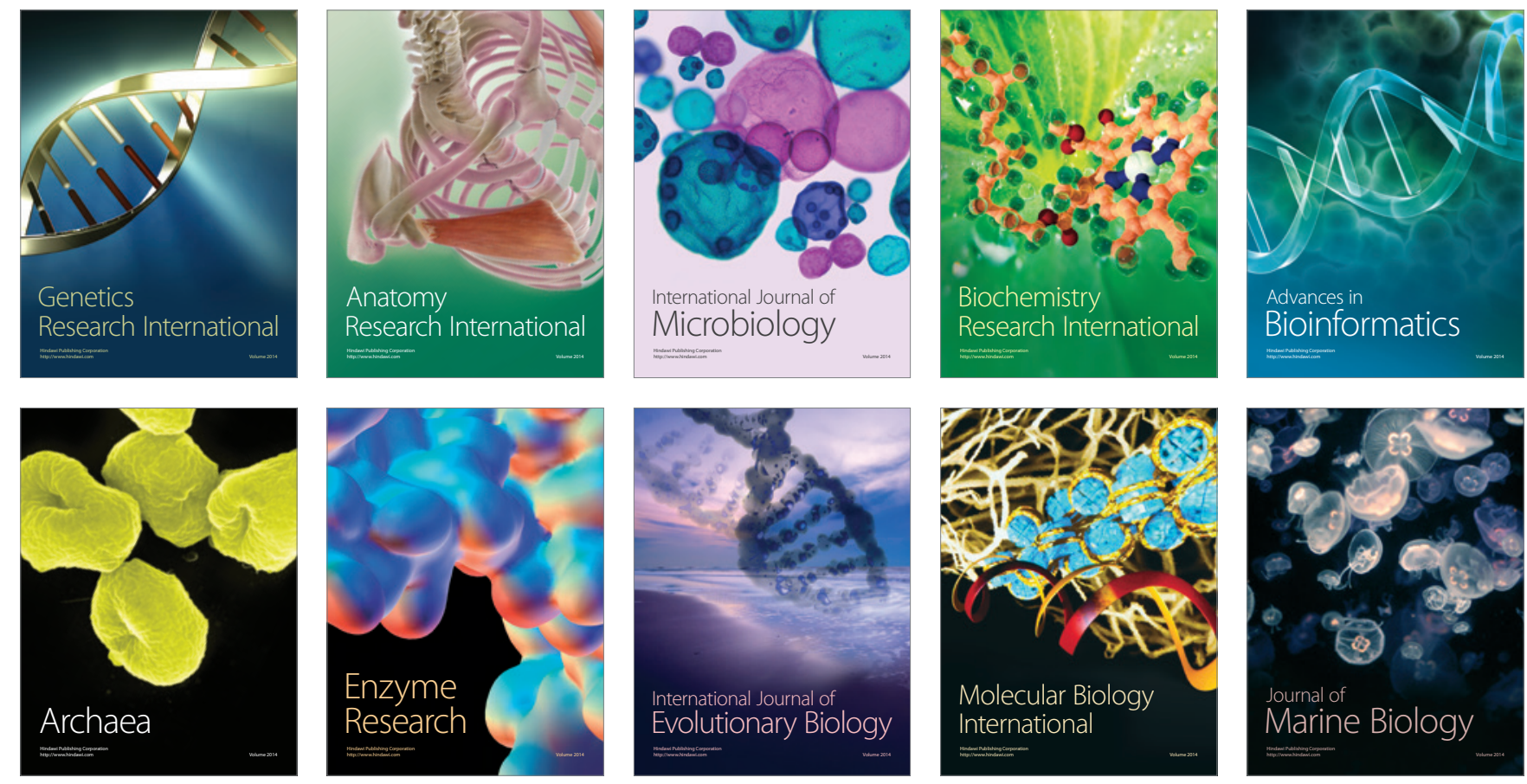